\title{
Screenings of Four Medicinal Plants of Bangladesh for Bioactivities
}

\author{
Md. Al Amin Sikder¹, Tasnuva Sharmin², A. F. M. Mustafizur Rahman³, \\ Mohammad Rashedul Haque ${ }^{1}$, Mohammad S. Rahman ${ }^{1}$ and \\ Mohammad A. Rashid ${ }^{1}$ \\ ${ }^{1}$ Department of Pharmaceutical Chemistry, Faculty of Pharmacy, University of Dhaka, \\ Dhaka-1000, Bangladesh. \\ ${ }^{2}$ Department of Pharmacy, State University of Bangladesh, Dhaka-1205, Bangladesh \\ ${ }^{3}$ Department of Applied Chemistry and Chemical Engineering, University of Dhaka, Dhaka-1000, Bangladesh.
}

\begin{abstract}
The methanol extracts of leaves of Nephelium lappaceum L., Pandanus foetidus Roxb., Ludwigia repens Rubin. and the whole plant of Adiantum philippense L. were subjected to assays of antioxidant, cytotoxic, thrombolytic and membrane stabilizing activities. The antioxidant activity was evaluated by DPPH free radical scavenging activity using butylated hydroxytolune and ascorbic acid as standards. The crude extract of $N$. lappaccam exhibited the highest free radical scavenging activity $\left(\mathrm{IC}_{50}=3.93 \pm 0.25 \mu \mathrm{g} / \mathrm{ml}\right.$ ). On the other hand, the crude methanol extracts of $A$. philippense and $P$. foetidus demonstrated significant brine shrimp lethality with $L_{50}$ values $0.50 \pm 0.84$ $\mu \mathrm{g} / \mathrm{ml}$ and $0.58 \pm 0.73 \mu \mathrm{g} / \mathrm{ml}$, respectively as compared to the standard anti-neoplastic drug, vincristine sulfate $\left(\mathrm{LC}_{50}=\right.$ $0.45 \mu \mathrm{g} / \mathrm{ml}$ ). Weak thrombolytic activity was observed for the test samples. The crude methanol extracts of $P$. foetidus and $N$. lappaceum showed $17.31 \pm 0.82 \%$ and $17.29 \pm 0.91 \%$ clot lysis while standard streptokinase and water, used as positive and negative controls, demonstrated $66.77 \%$ and $3.79 \%$ lysis of clot, respectively. The methanol extract of whole plant of A. philippense inhibited hypotonic solution and heat induced haemolysis of RBCs by $53.09 \pm 1.01 \%$ and $35.36 \pm 1.60 \%$ as compared to $71.77 \%$ and $42.20 \%$ by acetyl salicylic acid, respectively.

Key words: Nephelium lappaceum, Pandanus foetidus, Ludwigia repens, Adiantum philippense free radical scavenging, thrombolysis, haemolysis
\end{abstract}

\section{INTRODUCTION}

Nephelium lappaceum L. (Synonym: Nephelium lappaceum Rind.) commonly known as rambutan, is a medium-sized tropical tree belonging to Sapindaceae family. The fruit produced by the tree is also known as rambutan. The plant possesses antihyperglycemic activity. Geraniin and an ellagitannin were identified as the major bioactive constituents from N. lappaceum. ${ }^{1}$

Pandanus foresides Roxb. (Synonym: Fisquetia macrocarpa Gaudich.; Bengali name: Keya-kanta) is a branched shrub with few prop roots belonging to the family Pandanaceae. The methanol extract of the leaves of $P$. foetidus has neuropharmacological

Correspondence to: Mohammad A. Rashid

Tel.: 880-2-9661900, Extn.- 8137, 8131, Fax: 880-2-8615583

E-mail address: rashidma@du.ac.bd

Dhaka Univ. J. Pharm. Sci. 12(1): 59-62, 2013 (June) activities. It significantly prolonged the pentobarbitone induced sleeping time in mice and showed mild to moderate central nervous system depressant activity when assessed in mice model. ${ }^{2}$

Ludwigia repens Rubin. (Synonyms: Ludwigia natans Elliott., Isnardia intermedia Small and Alexander; Benali names: Kesardam, Mulcha, Mulsi) commonly known as creeping primrose willow, is a flowering plant belonging to the family Onagraceae. This is a mat forming perennial herb with a creeping stem up to $30 \mathrm{~cm}$ long. The methanol extract of leaves possesses CNS depressant analgesic activity. The extract significantly accelerated onset of sleep and maximized the duration of sleeping time when administered with thiopental sodium. ${ }^{3}$

Adiantum philippense L. (Synonym: Adiantum lunulatum Burm. f., Bengali names: Goyalelata, 
Kalijhant) locally known as walking maiden hair fern, is a small fern belonging to the family Adiantaceae. The plant has demulcent, astringent and emenagogue properties. It is used in the treatment of cough, asthma, fever, leprosy and hair fall. ${ }^{4}$ Leaf paste with sugar is given in spermatorrhoea once a day for one month. ${ }^{5}$

As part of our ongoing investigations on medicinal plants of Bangladesh ${ }^{6,7}$, the methanol extracts of leaves of $N$. lappaceum, $P$. foetidus, $L$. repens and the whole plant of $A$. philippense growing in Bangladesh were studied for the antioxidant potential in terms of free radical scavenging property; cytotoxic, thrombolytic and membrane stabilizing activities for the first time and we, here in, report the results of our preliminary investigations.

\section{MATERIALS AND METHODS}

Plant materials. The leaves of $N$. lappaceum, $P$. foetidus, $L$. repens and the whole plant of $A$. philippense were collected from Kishoregonj in March, 2011. Voucher specimens for these plants have been maintained in Bangladesh National Herbarium, Dhaka, Bangladesh for future references.

The collected plant materials were cleaned, sun dried and pulverized. The powdered materials (500 g each) were separately soaked in 2.0 liters of methanol at room temperature for 7 days. The extracts were filtered through fresh cotton bed and finally with Whatman filter paper number 1 and concentrated with a rotary evaporator at reduced temperature (40$45^{\circ} \mathrm{C}$ ) and pressure. The residues were then stored in a refrigerator until further use.

DPPH free radical scavenging assay. Following the method developed by Brand-Williams et al. $(1995)^{8}$ the antioxidant activity of the test samples was assessed by evaluating the scavenging activities of the stable 1,1-diphenyl-2-picrylhydrazyl (DPPH) free radical by using synthetic antioxidants, butylated hydroxytoluene (BHT) and ascorbic acid as positive controls.
Brine shrimp lethality bioassay. This technique was applied for the determination of general toxic properties of the DMSO solutions of plant extractives against Artemia salina in a one day in vivo assay ${ }^{9}$. Here, vincristine sulphate was used as positive control.

Thrombolytic activity. The thrombolytic activity was evaluated by the method developed by Prasad et al. (2006) $)^{10}$ by using streptokinase as positive control.

Membrane stabilizing activity. The membrane stabilizing activity of the extractives was assessed by evaluating their ability to inhibit hypotonic solutionand heat- induced haemolysis of human erythrocytes following the method developed by Omale et al. (2008). ${ }^{11}$

Statistical analysis. For all bioassays, three replicates of each sample were used for statistical analysis and the values are reported as mean \pm SD.

\section{RESULTS AND DISCUSSION}

Four medicinal plants $N$. lappaccam, $P$. foctidus, L. repenus and A. philippense growing in Bangladesh and belonging to the family Sapindaceae, Pandanaceae, Onagraceae and Adiantaceae, respectively have been investigated for antioxidant potential in terms of total phenolic content and free radical scavenging property as well as cytotoxic, thrombolytic and membrane stabilizing activities.

The methanolic crude extracts of leaf of $P$. foetidus, $N$. lappaceum, $L$. repens and whole plant of A. philippense were subjected to DPPH free radical scavenging activity assay. The highest free radical scavenging activity was demonstrated by the methanol extracts of $N$. lappaccam $\left(\mathrm{IC}_{50}=\right.$ $3.93 \pm 0.25 \mu \mathrm{g} / \mathrm{ml})$ followed by the A. philippense extract $\left(\mathrm{IC}_{50}=56.50 \pm 2.50 \mu \mathrm{g} / \mathrm{ml}\right.$ ) (Table 1$)$.

In brine shrimp lethality bioassay, the crude methanol extracts of $A$. philippense $\left(\mathrm{LC}_{50}=0.50 \pm 0.84\right.$ $\mu \mathrm{g} / \mathrm{ml}$ ) and $P$. foetidus ( $\mathrm{LC}_{50}=0.58 \pm 0.73 \mu \mathrm{g} / \mathrm{ml}$ ) demonstrated the presence of considerable bioactive principles (Table 1). 
Table 1. The free radical scavenging and cytotoxic activities of the methanol extracts of $N$. lappaceum, P. foetidus, $L$. repens and $A$. philippense and reference standards.

\begin{tabular}{lcc}
\hline Samples/ Standards & $\begin{array}{c}\text { DPPH Free radical scavenging } \\
\text { activity }\left(\mathrm{IC}_{50} \mu \mathrm{g} / \mathrm{ml}\right)\end{array}$ & $\begin{array}{c}\text { Cytotoxic activity } \\
\left(\mathrm{LC}_{50} \mu \mathrm{g} / \mathrm{ml}\right)\end{array}$ \\
\hline N. lappaccam & $3.93 \pm 0.25$ & $77.64 \pm 0.45$ \\
$P$. foctidus & $1093.85 \pm 4.01$ & $0.58 \pm 0.73$ \\
L. repenus & $707.23 \pm 2.54$ & $8.85 \pm 0.56$ \\
A. philippense & $56.50 \pm 2.50$ & $0.50 \pm 0.84$ \\
\hline Butylated hydroxytolune & $26.65 \pm 0.99$ & - \\
Ascorbic acid & $5.63 \pm 0.58$ & - \\
Vincristine sulfate & - & $0.45 \pm 0.45$ \\
\hline
\end{tabular}

All the test samples demonstrated weak thrombolytic activity. P. foetidus and N. lappaceum extracts showed $17.31 \pm 0.82 \%$ and $17.29 \pm 0.91 \%$ clot lysis, respectively while standard streptokinase revealed $66.77 \%$ lysis of clot (Table 2).

Table 2. Thrombolytic activity of methanol extracts of $N$. lappaceum, $P$. foetidus, $L$. repens and $A$. philippense.

\begin{tabular}{lc}
\hline Samples/ Standards & \% of lysis of RBC \\
\hline N. lappaccam & $17.29 \pm 0.91$ \\
P. foctidus & $17.31 \pm 0.82$ \\
L. repenus & $9.89 \pm 0.35$ \\
A. philippense & $16.56 \pm 1.41$ \\
Water & $3.79 \pm 0.55$ \\
\multicolumn{1}{c}{ Streptokinase } & $66.77 \pm 0.36$ \\
\hline
\end{tabular}

The methanol extract of whole plant of $A$. philippense, at concentration $1.0 \mathrm{mg} / \mathrm{ml}$, exhibited significant membrane stabilizing activity as compared to the standard acetyl salicylic acid (0.10 $\mathrm{mg} / \mathrm{mL}$ ). This extract inhibited hypotonic solutionand heat- induced haemolysis of RBCs by $53.09 \pm 1.01 \%$ and $35.36 \pm 1.60 \%$ as compared to $71.77 \%$ and $42.20 \%$ inhibited by acetyl salicylic acid, respectively (Table 3).

Table 3. Effect of methanol extracts of $N$. lappaceum, $P$. foetidus, $L$. repens and of $A$. philippense on heat- and hypotonic solutioninduced haemolysis of erythrocyte membrane.

\begin{tabular}{ccc}
\hline Sample code & \multicolumn{2}{c}{ \% inhibition of haemolysis } \\
\cline { 2 - 3 } & Heat induced & Hypotonic solution induced \\
\hline N. lappaccam & $33.61 \pm 0.71$ & $40.75 \pm 0.25$ \\
P. foctidus & $30.19 \pm 1.63$ & $11.22 \pm 0.80$ \\
L. repenus & $30.16 \pm 0.89$ & $34.25 \pm 0.72$ \\
A. philippense & $35.36 \pm 1.60$ & $53.09 \pm 1.01$ \\
Acetyl salicylic acid & $42.20 \pm 1.65$ & $71.77 \pm 0.95$ \\
\hline
\end{tabular}

The investigated plants are reported to have many important traditional uses. The smashed leaf of $N$. lappaccam is used by the Kensiu Tribe of Lubuk Ulu Legong, Kedah, Malaysia for the treatment of influenza fever. ${ }^{12} P$. foctidus has extensive medicinal uses. The plant has neuropharmacological activity and is used in leprosy, smallpox, syphilis, scarbies and leucoderma. Leaves are alexiteric, tonic and aphrodisiac and are used in diabetes. ${ }^{13}$ The methanol extract of leaves of $L$. repenus possesses analgesic activity. ${ }^{3}$ The leaf paste of $A$. philippense is used for immediate relief of indigestion. ${ }^{14}$ It is clearly evident from the above findings that the crude methanol extracts of $N$. lappaccam, $P$. foctidus, $L$. repenus and A. philippense possess significant bioactive principles. It is clearly evident from the above findings that the crude methanol extracts of $N$. lappaccam, $P$. foctidus, $L$. repenus and A. philippense possess significant bioactive principles and these results are consistent with some of the folkloric uses of the plant. Therefore, these medicinal plants are good candidates for further systematic, chemical and biological investigation to isolate the active constituents. 


\section{ACKNOWLEDGEMENT}

The authors wish to acknowledge the supports of State University of Bangladesh for providing some laboratory facilities to carry out some of the experiments.

\section{REFERENCES}

1. Palanisamy, U.D., Ling, L.T., Manaharan, T. and Appleton, D. 2011. Rapid isolation of geranin from Nephelium lappaceum rind waste and its anti-hyperglycemic activity. Food Chemistry 127, 21-27.

2. Uddin, S.J., Shilpi, J.A., Rahman, M.T., Ferdous, M.M., Rouf, S.D. and Sarker, S.D. 2006. Assessment of neuropharmacological activities of Pandanus foetidus (Pandanaceae) in mice. Die Pharmazie. 61, 362-364.

3. Uddin, M.E., Islam, A.M.T., Chowdhury, M.A.U., Rahman, M.K. and Islam, M.S. and Islam, M.R. 2012. Sedative and Analgesic Activities of Ludwigia repens. Phytopharmacology 2, 202-211.

4. Upreti, K., Jalal, J.S., Tewari, L.M., Joshi, G.C., Pangtey, Y.P.S. and Tewari, G. 2009. Ethnomedicinal uses of Pteridophytes of Kumaun Himalaya, Uttarakhand, India. $J$. American Sci. 5, 167-170.

5. Skarwar, R.L.S., Pathak, B. and Jaiswal, A. 2008. Some unique ethnomedical perception of tribal communities of Chitrakoot, Madhya Pradesh. Indian J. Traditional Knowledge 7, 613-617.

6. Kaisar, M.A., Rahman, M.S., Rahman, M.Z., Hasan, C.M. and Rashid, M.A. 2011. A review on phytochemicals from some medicinal plants of Bangladesh. J. Phar. Nutri. Sci. 1, 87-95.
7. Sharmin, T., Islam, F., Kaisar, M.A., Uddin, M.G. and Rashid, M.A., 2012. Antioxidant, Thrombolytic and Cytotoxic Activities of Picrasma javanica. Dhaka Univ. J. Pharm. Sci. 11. 71-74.

8. Brand-Williams, W., Cuvelier, M.E. and Berset, C. 1995. Use of free radical method to evaluate antioxidant activity. Lebensm. Wiss. Technol. 28, 25-30.

9. Meyer, B.N., Ferringni, N.R., Puam, J.E., Lacobsen, L.B., Nichols, D.E. and McLaughlin, J.L. 1982. Brine shrimp: a convenient general bioassay for active constituents. Planta Med. 45, 31-32.

10. Prasad, S., Kashyap, R.S., Deopujari, J.Y., Purohit, H.J., Taori, G.M. and Daginawala, H.F. 2007. Effect of Fagonia Arabica (Dhamasa) on in vitro thrombolysis, BMC Complement. Alternat. Med. 7:36 doi: 10.1186/1472-6882-736.

11. Omale, J. and Okafor, P.N. 2008. Comparative antioxidant capacity, membrane stabilization, polyphenol composition and cytotoxicity of the leaf and stem of Cissus multistriata. Afr. J. Biotechnol. 7, 3129-3133.

12. Mohammad, N.S., Milow, P. and Ong, H.C. 2012. Traditional Medicinal Plants Used by the Kensiu Tribe of LubukUlu Legong, Kedah, Malaysia. Ethno. Med. 6, 149153.

13. Hossain, M.L., Hossain, M.A.A.S.M., Kumar, S.K., Hossin, A. and Rahman, M.A. 2013. Phytochemical screening and the evaluation of the antioxidant, total phonelic content and analgesic properties of the plant Pandanus foetidus (Family: Pandanaceae). Inter. Res. J. Phar. 4, 170-172.

14. Rout, S.D., Panda, T. and Mishra, N. 2009. Ethnomedicinal studies on some pteridophytes of Similipal Biosphere Reserve, Orissa, India. Inter. J. Med. Med. Sci. 1, 192-197. 